\title{
Economic efficiency calculation of production of functional product based on milk serum and medicinal plant extract at the food industry enterprise
}

\author{
Alexsandr Prosekov ${ }^{1}$, Tatiana Alabina ${ }^{2}$, Evgeny Bryukhachev ${ }^{1,3}$, and Alexandra \\ Zaushintsena ${ }^{3, *}$ \\ ${ }^{1}$ Kemerovo State University, Department of Bionanotechnology, 650043 Kemerovo, Russia \\ ${ }^{2}$ Kemerovo State University, Department of Finance and Credit, 650043, Kemerovo, Russia \\ ${ }^{3}$ Kemerovo State University, Department of Ecology and Nature Management, 650043, Kemerovo, \\ Russia
}

\begin{abstract}
Possibility of medicinal plants use in the production of functional products on the example of whey beverage based on rosewort liquid concentrate, which has immunomodulatory, antioxidant, antitumor, nootropic, antidepressant properties, having a multifunctional value in the application, is proved in the works of different authors. The paper offers process and technological production scheme of pasteurized whey beverage with apple juice and pulp enriched with biologically active substances of rosewort "Golden Reserve". The economic efficiency of beverage introduction into production at the operating process line of food industry enterprise "MPA (Milk production association) "Skomoroshka"" LLC located in Kemerovo region (Kuzbass) is calculated for mid-term. Average market prices for raw materials and finished products are taken into account by the following indicators: expenses, cost, results, cash flow and others based on accounting and economic approaches taking into account non-stationarity of the Russian economy.
\end{abstract}

\section{Introduction}

Rhodiola rosea L. has beneficial properties for the human body. From its raw materials medicinal products, cosmetological products, functional food products for different age categories of the population are prepared [1-4]. Serum beverage enriched with the biologically active substances of rosewort, has a high content of salidroside, rosovine and other biologically active substances (BAS).

During the analysis of scientific literature, the relevance of whey use as the basis of a new functional beverage [5] was proved; it is introduced into the current production on food industry enterprises of Kemerovo region (Kuzbass) - "Milk production association "Skomoroshka"" ("MPA "SKOMOROSHKA“" LLC). For this purpose, it is necessary to

*Corresponding author: alexaz58@yandex.ru 
define the main parameters not only of the formulation, which was previously made by the authors [6], but also to establish the process scheme and process flow diagram of its production, to identify the required volume of financial investments on the part of this enterprise, to assess the effectiveness of the invested funds.

\section{Materials and Methods}

During the study, the following were used:

- Algorithmic approach in the process scheme development of the production line of functional purpose whey beverage.

- Process diagram at graphical designation of whey beverage production line.

- The non-stationarity approach to the Russian economy, when management decisions and business processes at the food industry enterprise are prepared depending on the situation and economic environment features based on a systemic set of available information, rational and irrational considerations in its processing, taking into account different, including non - monotonic and non-smooth dynamical processes, components, financial elements and systems that are difficult to predict [7].

- Calculation method of the production cost computation of the product for production economic efficiency calculation of functional purpose whey beverage based on rosewort (accounting approach).

- Elements of the efficiency evaluation method of investment projects for economic efficiency calculation of beverage introduction into production on the operating process line of the food enterprise industry in a non-stationary economy (economic approach).

The normative-methodical basis was:

- Normative technical documentation to characterize the production process of the product, - separate state industry standards and technical conditions TU 10.51.55-001-020683092019.

- Methodical recommendations on investment projects efficiency evaluation approved by the Ministry of Economy of the Russian Federation, the Ministry of Finance of the Russian Federation, the State Committee for Construction, Architectural and Housing Policy No. VK 477 of June 21, 1999. They are used to determine the effectiveness of the production of pasteurized whey beverage with apple juice and pulp enriched with biologically active substances of rosewort ( Rhodiola rosea L.) at a food industry enterprise in non-stationary conditions of the Russian economy.

\section{Results and Discussion}

The production process at the enterprises of the food industry includes a number of elements: process line of the established type, product formulation, financial, material, labor resources and other production parameters and processes.

\subsection{Technological bases of production of pasteurized whey beverage with apple juice and pulp enriched with biologically active substances of rosewort}

Production of functional whey beverage using liquid concentrate of the medicinal plant Rhodiola rosea L. is based on process scheme and process flow diagram of its manufacturing line. Process flow diagram of this beverage production from milk whey (Figure 1) is intended for use in enterprises of milk processing industry and implemented in Kemerovo region (Kuzbass) on the basis of "MPA "SKOMOROSHKA" " LLC 

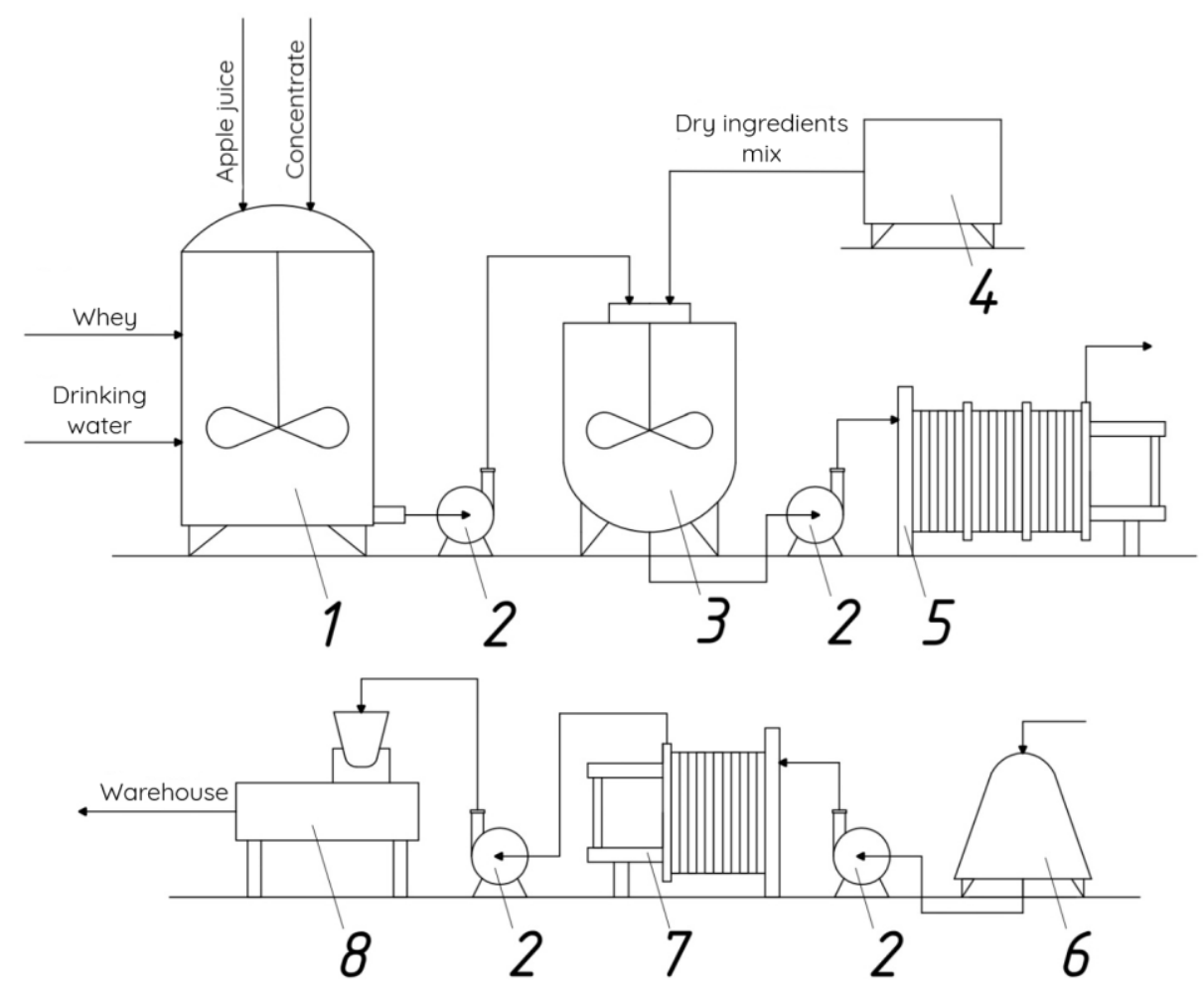

Fig. 1. Process flow diagram of production of pasteurized whey beverage with apple juice and pulp enriched with biologically active substances of rosewort in "MPA "SKOMOROSHKA" LLC: 1, 3 — tanks of different volume (with stirring device); 4 - mixer; 2 - centrifugal pump; 5 pasteurization and cooling unit, 6 - homogenizer, 7 - cooling unit; 8 - filling machine.

Based on the algorithmic approach, the process flow diagram of the functional direction whey beverage production line with the addition of liquid rosewort concentrate includes a number of stages, presented in Figure 2.

(1) Acceptance and evaluation of the quality of raw materials coming to the enterprise, passing it into production to the process line

(2) Preparation of liquid components mixture

(whey, drinking water, apple juice,

liquid rosewort concentrate)

(3) Preparation of dry components mixture (sugar, apple pectin, citric acid)

(4) Preparation of recipe mixture

(5) Pasteurization of finished mixture $\mathrm{t}=80-85^{\circ} \mathrm{C}, \tau=15-18 \mathrm{sec}$

(6) Mixture homogenization $\mathrm{t}=59-62{ }^{\circ} \mathrm{C}$ 


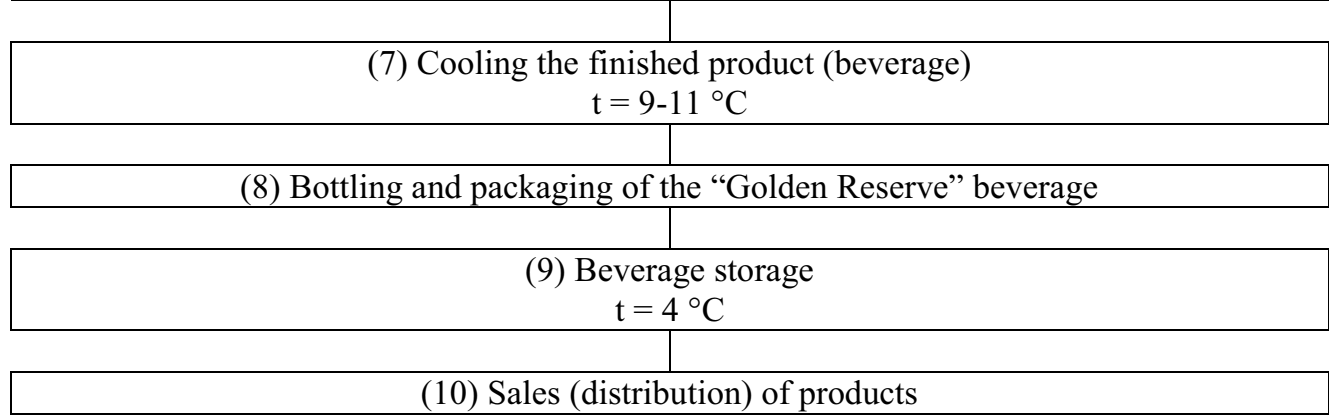

Fig. 2. Block diagram of production processes of pasteurized whey beverage with apple juice and pulp enriched with biologically active substances of rosewort in "MPA "SKOMOROSHKA" " LLC.

The raw materials coming to the enterprise are evaluated on the basis of a certain package of documents confirming it:

- For raw materials of domestic production - certificate of conformity and quality certification.

- For raw materials of foreign production - the conclusion of the Federal Service for Supervision in the Field of Consumer Protection and Human Welfare (Rospotrebnadzor) and the manufacturer's certificate.

For structure uniformity of the "Golden Reserve" finished functional drink, preparation of its original mixture is carried out sequentially. Initially, a mixture of liquid components is made. For this purpose, whey, drinking water and apple juice are supplied to the tank through the pipeline. In manual mode, liquidRhodiola rosea L. concentrate is introduced. Then a mixture of dry ingredients is prepared. They are supplied to a screw mixer. In it, thorough mixing of components occurs. Next, the mixture of liquid components is pumped into the next tank using a centrifugal pump. After that, a mixture of dry ingredients is poured into the stirring device and everything is thoroughly mixed.

The finished mixture is supplied by the centrifugal pump to the pasteurization and cooling unit. The mixture is heated to a temperature of $80-85{ }^{\circ} \mathrm{C}$ and cured for $15-18$ seconds. After curing, the mixture is cooled in the recovery section to a temperature of 59$62{ }^{\circ} \mathrm{C}$., This technique suppresses the development of vegetative forms of microorganisms and increases the shelf life of the finished beverage.

Immediately after pasteurization, the whey beverage enters the homogenizer to obtain uniform, even consistency. The homogenized beverage is cooled in the cooling unit to a temperature of $9-11{ }^{\circ} \mathrm{C}$. The finished product is delivered to the filling line, packaged in containers and shipped to the warehouse under the name "Golden Reserve" for storage at 4 ${ }^{\circ} \mathrm{C}$, followed by its distribution and supply to the end consumer.

\subsection{Calculation of economic efficiency of production of pasteurized whey beverage with apple juice and pulp enriched with biologically active substances of rosewort, on an active process line of the dairy industry enterprise in non-stationary Russian economy}

The key parameters in assessing the feasibility of implementation and calculating the efficiency of technological production of any product are associated with it costs and useful results. Depending on the differences in the economic conditions in which the enterprise of the dairy food processing industry operates, there is a talk about stationarity or nonstationarity of the economy. Therefore, before assessing the economic efficiency of production, it is necessary to determine the external environment of its functioning. 
Economists proved [8] that the modern economy of Russia has a non-stationary market character. The term "stationary economy" represents "... the economic system inherent to well-off industrialized countries operating in a non - crisis period, the most important macro - economic parameters and performance indicators of which remain unchanged or change relatively smoothly" [9]. The concept of "non-stationary economy" reflects a situation of some or temporary instability in the country's economy. This is reflected in sharp differences, unsustainable dynamics of financial elements and systems components that are quite difficult to predict. Such sharp fluctuations should be taken into account when evaluating the introduction of any product into production.

In order to determine the economic efficiency of whey beverage production on the basis of liquid rosewort concentrate, the computation of cost calculation by calculating method is performed (accounting approach). The calculation of costs for main and auxiliary raw materials used in the production of the beverage at the given average market prices for it is presented in Table 1.

Table 1. Expenses calculation of "MPA "SKOMOROSHKA" " LLC for operating process line on main and auxiliary raw materials in the production of 1 ton of pasteurized whey beverage with apple juice and pulp enriched with biologically active substances of rosewort

\begin{tabular}{|l|c|c|c|}
\hline $\begin{array}{c}\text { Nomenclature of raw } \\
\text { materials } \\
\text { (ingredient) }\end{array}$ & $\begin{array}{c}\text { Wholesale price of } \\
\text { raw material unit, } \\
\text { RUB/kg }\end{array}$ & $\begin{array}{c}\text { Raw material } \\
\text { consumption per 1 t } \\
\text { of product }\end{array}$ & $\begin{array}{c}\text { Costs for raw } \\
\text { materials for } \\
\text { production of 1 t of } \\
\text { product, RUB. }\end{array}$ \\
\hline Whey, kg & 10.0 & 500.0 & 5500.0 \\
\hline Apple juice, kg & 18.0 & 200.0 & 3600.0 \\
\hline Drinking water, kg & 0.05 & 300.0 & 15.0 \\
\hline Sugar, kg & 23.0 & 30.0 & 690.0 \\
\hline Apple pectin, kg & 1000.0 & 5.0 & 3000.0 \\
\hline $\begin{array}{l}\text { Rosewort concentrate, } \\
\mathrm{kg}\end{array}$ & 3000.0 & 1.0 & 28.0 \\
\hline Lemon acid, $\mathrm{kg}$ & 70.0 & 0.4 & 16665.0 \\
\hline Bottle $300 \mathrm{ml}, \mathrm{pcs}$. & 5.0 & 3333 & 34498.0 \\
\hline Total & \multicolumn{3}{|l}{} \\
\hline
\end{tabular}

Expenses calculation showed that this enterprise of Kuzbass food industry will bear approximately 34.5 thousand rubles per 1 ton whey beverage on the operating technological line for main and auxiliary raw materials.

The full cost of production expenses per $1 \mathrm{t}$ of the product is shown in Table 2 and is more than 61 thousand rubles.

Table 2. Production cost of 1 ton functional whey beverage based on liquid rosewort concentrate for operating technological line in "MPA "SKOMOROSHKA" "LLC

\begin{tabular}{|l|c|c|}
\hline \multicolumn{1}{|c|}{ Cost items } & Volume, rub. & $\begin{array}{c}\text { Specific weight, } \\
\text { \% }\end{array}$ \\
\hline Raw materials and materials & 34499.0 & 56.45 \\
\hline Electricity, water, fuel for technological purposes & 1363.76 & 2.23 \\
\hline
\end{tabular}




\begin{tabular}{|l|c|c|}
\hline Payroll contributions & 8611.75 & 14.09 \\
\hline Social contributions & 2600.45 & 4.26 \\
\hline Production preparation and development costs & 1533.92 & 2.51 \\
\hline General production costs & 5201.67 & 8.51 \\
\hline Workshop production cost for 1 tof beverage & $\mathbf{5 3 8 1 0 . 5 5}$ & $\mathbf{8 8 . 0 5}$ \\
\hline General running costs & 5879.02 & 9.62 \\
\hline Losses from defects & 177.23 & 0.29 \\
\hline Other manufacturing expenses & 1246.69 & 2.04 \\
\hline \multicolumn{1}{|c|}{ Total cost per 1 t beverage } & $\mathbf{6 1 1 1 3 . 4 9}$ & $\mathbf{1 0 0}$ \\
\hline
\end{tabular}

More than $50 \%$ of the product cost is on the main raw materials and materials, and almost $90 \%$ of the cost of $1 \mathrm{t}$ of beverage production is formed directly on the process line in the workshop.

The calculation of the main indicators of whey beverage production is presented in Table 3.

Table 3. Main indicators of 1 ton production of pasteurized whey beverage with apple juice and pulp enriched with biologically active substances of rosewort, "Golden reserve" for operating technological line in "MPA "SKOMOROSHKA“" LLC

\begin{tabular}{|l|c|}
\hline \multicolumn{1}{|c|}{ Indicator name } & Value \\
\hline Cost of 1 t of beverage, rub. & 61113.49 \\
\hline Number of product per batch, pcs. & 3333 \\
\hline Cost of 1 beverage unit (300 ml), rub. & 18.33 \\
\hline Production profitability, \% & 30.0 \\
\hline Profit, RUB/t & 18333.79 \\
\hline Wholesale beverage price, RUB/t & 79447.28 \\
\hline Value Added Tax, \% & 20.0 \\
\hline Beverage sale price, RUB/t & 95336.74 \\
\hline Distribution margin, $\%$ & 25.0 \\
\hline Beverage retail price, RUB/t & 119170.93 \\
\hline Retail price per 1 beverage unit $(300 \mathrm{ml})$, rub. & 35.76 \\
\hline
\end{tabular}

The cost of one bottle of functional purpose whey beverage with the addition of a liquid rosewort concentrate with a capacity of $300 \mathrm{ml}$ will be 18.33 rubles. Market value of the 
beverage taking into account $30 \%$ production profitability and $20 \%$ value added tax will amount to 35.76 rubles. The expected profit from $1 \mathrm{t}$ of production will be 18333.79 rubles.

To calculate the economic efficiency of the production of pasteurized whey beverage with apple juice and pulp enriched with biologically active substances of rosewort, "Golden Reserve", namely the commercial efficiency of the enterprise's participation in the project, some elements of the methodology for assessing the effectiveness of investment projects developed by the authors' team were used, one of whom is Dr. of Economics, Professor V. $\mathrm{N}$. Livshits, as indicated in the Methodological Recommendations on efficiency assessment of investment projects No. VC 477 of June 21, 1999. The economic approach to the production efficiency calculation is based on economic profit, which differs from accounting by the amount of implicit costs or loss of profits, which are not reflected in the accounting [10].

Net Present Value (NPV) in market economy is calculated using the formula (1):

$$
N P V=-\mathrm{K}+\sum_{t+1}^{t=T} \frac{R(t)-C(t)}{(1+E)^{t}}
$$

where $K$ is the initial investment;

$R(t)$ - money inflow in $t$ year;

$C(t)$ - money outflow in $t$ year;

$T$ - life cycle duration;

$E(0.25)$ - the discount rate.

The condition of the investment project efficiency, and in our case of the given product is fulfilled at $N P V \geq 0$ [10].

The calculation of commercial efficiency of the beverage production is presented in Table 4.

Table 4. Commercial efficiency calculation of production of pasteurized whey beverage with apple juice and pulp enriched with biologically active substances of rosewort, "Golden reserve" on operating process line for "MPA "SKOMOROSHKA" "LLC *

\begin{tabular}{|c|c|c|c|c|c|c|}
\hline Indicators & $\mathbf{2 0 1 9}$ & $\mathbf{2 0 2 0}$ & $\mathbf{2 0 2 1}$ & $\mathbf{2 0 2 2}$ & $\mathbf{2 0 2 3}$ & $\mathbf{2 0 2 4}$ \\
\hline $\begin{array}{c}\text { Proceeds from products } \\
\text { sales, mln. RUB }\end{array}$ & - & 60.062 & 60.062 & 60.062 & 60.062 & 60.062 \\
\hline $\begin{array}{c}\text { Revenues from the sale of } \\
\text { the license agreement in } \\
\text { accordance with the patent, } \\
\text { thousand rubles. }\end{array}$ & - & 35.0 & 35.0 & 35.0 & 35.0 & 35.0 \\
\hline $\boldsymbol{R}$ (t), million rubles. & - & $\mathbf{6 0 . 0 9 7}$ & $\mathbf{6 0 . 0 9 7}$ & $\mathbf{6 0 . 0 9 7}$ & $\mathbf{6 0 . 0 9 7}$ & $\mathbf{6 0 . 0 9 7}$ \\
\hline $\begin{array}{c}\text { Depreciable cost of } \\
\text { production line, mln.RUB }\end{array}$ & 18.000 & - & - & - & - & - \\
\hline $\begin{array}{c}\text { Raw materials and materials, } \\
\text { million rubles. }\end{array}$ & - & 26.081 & 26.081 & 26.081 & 26.081 & 26.081 \\
\hline $\begin{array}{c}\text { Electricity, water, fuel for } \\
\text { technological purposes, } \\
\text { mln.RUB }\end{array}$ & - & 1.031 & 1.031 & 1.031 & 1.031 & 1.031 \\
\hline $\begin{array}{c}\text { Payroll contributions, } \\
\text { mln.RUB }\end{array}$ & - & 6.510 & 6.510 & 6.510 & 6.510 & 6.510 \\
\hline $\begin{array}{c}\text { Social contributions, } \\
\text { mln.RUB }\end{array}$ & - & 1.966 & 1.966 & 1.966 & 1.966 & 1.966 \\
\hline $\begin{array}{c}\text { Expenses for preparation and } \\
\text { development of production, } \\
\text { mln.RUB }\end{array}$ & 1.160 & - & - & - & - & - \\
\hline
\end{tabular}




\begin{tabular}{|c|c|c|c|c|c|c|}
\hline $\begin{array}{l}\text { Depreciation reserves, } \\
\text { thousand rubles. }\end{array}$ & - & 25.5 & 25.5 & 25.5 & 25.5 & 25.5 \\
\hline $\begin{array}{l}\text { Acquisition of a patent, } \\
\text { thousand rubles. }\end{array}$ & 3.5 & - & - & - & - & - \\
\hline$C(t)$, million rubles. & 19.163 & 35.614 & 35.614 & 35.614 & 35.614 & 35.614 \\
\hline Inflation rate $h(t), \%$ & 3.00 & 3.90 & 4.00 & 4.00 & 3.80 & 3.50 \\
\hline $\begin{array}{c}\text { Cash flow } R(t)-C(t), \\
\text { mln.RUB }\end{array}$ & -19.163 & 24.483 & 24.483 & 24.483 & 24.483 & 24.483 \\
\hline $\begin{array}{c}\text { General chain inflation index } \\
\qquad J(t)\end{array}$ & 1.030 & 1.039 & 1.040 & 1.040 & 1.038 & 1.035 \\
\hline $\begin{array}{l}\text { Base general inflation index } \\
G J(t)\end{array}$ & 1.000 & 1.039 & 1.081 & 1.124 & 1.166 & 1.207 \\
\hline Deflated flow, mIn.RUB & -19.163 & 23.564 & 22.658 & 21.786 & 20.989 & 20.279 \\
\hline $\begin{array}{c}\text { Discounted multiplier (at } E \\
=25 \% \text { ) }\end{array}$ & 1.000 & 0.800 & 0.640 & 0.512 & 0.410 & 0.328 \\
\hline $\begin{array}{c}\text { Discounted deflated flow, } \\
\text { mln.RUB }\end{array}$ & -19.163 & 18.851 & 14.501 & 11.155 & 8.597 & 6.645 \\
\hline \multicolumn{5}{|l|}{$N P V$} & \multicolumn{2}{|c|}{40.585} \\
\hline
\end{tabular}

${ }^{*}$ Methodology and algorithm of calculation according to [11].

$N P V$ calculation is adjusted taking into account non-stationarity of the Russian economy on the forecast inflation rate in accordance with the Bank of Russia's mid-term forecast following the meeting of the Board of Directors on the key rate on 24 April 2020 under changed conditions [12].

In year zero, there were no commercial results from the project. The costs of production commissioning were carried out. Since the life cycle of the project is the number of production years from the beginning of implementation to the complete failure and elimination of its consequences is unknown, then taking into account the consumer demand for the product it is considered advisable to release and implement the beverage for a limited period of 5 years. The average annual revenue from the product sale is planned in the amount of slightly more than 60 million rubles, taking into account the demand for similar products. The discounted multiplier is calculated at $E=25$. It is assumed to reinvest the company's profit in production at the maximum trading margin of $25 \%$.

As a result, commercial efficiency of production of pasteurized whey beverage with apple juice and pulp enriched with biologically active substances of rosewort, "Golden Reserve" on the operating technological line of the company "MPA "SKOMOROSHKA" "" LLC is proven, as NPV equals to over 40 million rubles, which is significantly more than 0.

\section{Conclusion}

This study shows the effectiveness of production introduction of a new pasteurized whey beverage with apple juice and pulp enriched with biologically active substances of rosewort. The current process line is opened at the enterprise of dairy processing industry of Kemerovo region - Kuzbass. The paper offers interconnected process flow diagram and process scheme of functional beverage production lines. On the basis of accounting and economic approaches to the enterprise efficiency assessment, the prospect of production technology introduction of functional beverage with apple juice and pulp, enriched with biologically active substances of rosewort has been confirmed in conditions of non- 
stationarity of the Russian economy on the basis of the main current and projected cash flows (costs - results).

\section{Acknowledgments}

The work was carried out within the framework of the Agreement No. 075-02-2018-223 of 26.11.2018 "Obtaining biologically active substances of medicinal plants of Siberia endemics using cultures of cells and organs of higher plants" (unique project identifier RFMEFI57718X0285).

\section{References}

1. A.V. Zaushintsena, E.V. Bryukhachev, Multifunctional value of rosewort, $L O W$ TEMPERATURE AND FOOD TECHNOLOGIES IN XXI CENTURY IX International Scientific and Technical Conference, 191-195 (2019)

2. C. Calcabrini, et al., Arch. Dermatol Res, 3, 191-200 (2010)

3. G.X. Mao, W.M. Xing, X.L. Wen, et al., Int. J. Cosmet. Sci., 37 (3), 321-328 (2015)

4. K. Pulok Mukherjee, et al., Phytomedicine, 19, 64-73 (2011)

5. E.V. Bryukhachev, A.V. Zaushintsena Use of medicine plants for development of functional products for skiers sportsmen, Innovation Convention "Kuzbass: education, science, innovation" Materials of the Innovative convention. Department of Youth Policy and Sports of the Kemerovo region. 121 - 122 (2019)

6. A. Zaushintsena, E. Bruhachev, O. Belashova, L. Asyakina, M. Kurbanova, A. Vesnina, N. Fotina, Foods and Raw Materials, 8 (1), 163-170 (2020)

7. V.N. Livchits, S.M. Kurmanova, System analysis of discounting methods in stationary and non-stationary economies and finance. System Analysis and Information Technologies (SAIT - 2017) Collection of proceedings of the Seventh International Conference, 546-552 (2017)

8. V.N. Livchits, T.I. Tishchenko, M.P. Frolova, S.V. Livehits, System effectiveness evaluation of large-scale measures in non-stationary Russian economy. Management of Large-Scale Systems Development MLSD'2019 Proceedings of the Twelfth International Conference, 118-126 (2019)

9. V.N. Livchits, S.V. Livehits System analysis of the non-stationary economy of Russia (1992-2009): Market Reforms, Crisis, Investment Policy, 452 (M.: Poly Print Service, 2010)

10. V.N. Livchits, I.A. Mironova, A.N. Shvetsov, Russian Journal of Industrial Economics 12 (1), 29-43 (2019)

11. P.L. Vilensky, V.N. Livchits, S.A. Smolyak, Evaluation of the Efficiency of Investment Projects: Theory and Practice, 1300 (M: Poli Print Service, 2015)

12. Bank of Russia Medium-Term Forecast at Key Rate Board Meeting on April 24, 2020 URL: https://cbr.ru/collection/collection/file/27833/forecast_200424.pdf 